Bull. Chem. Soc. Ethiop. 2013, 27(2), 273-280.

Printed in Ethiopia

DOI: http://dx.doi.org/10.4314/bcse.v27i2.12

ISSN 1011-3924

(c) 2013 Chemical Society of Ethiopia

\title{
N,N'-DIPYRIDOXYL(1,8-DIAMINO-3,6-DIOXAOCTANE) SCHIFF-BASE: SYNTHESIS, EXPERIMENTAL AND THEORETICAL IDENTIFICATION
}

\author{
S. Ali Beyramabadi ${ }^{1, *}$, Ali Morsali ${ }^{1}$, Mohammad Reza Bozorgmehr ${ }^{1}$, Malihe Javan \\ Khoshkholgh $^{2}$ and Abbas Ali Esmaeili ${ }^{2}$ \\ ${ }^{1}$ Department of Chemistry, Mashhad branch, Islamic Azad University, Mashhad, Iran \\ ${ }^{2}$ Department of Chemistry, School of Sciences, Ferdowsi University of Mashhad, Mashhad \\ 91775-1436, Iran
}

(Received November 14, 2011; revised January 14, 2013)

\begin{abstract}
The N,N'-dipyridoxyl(1,8-diamino-3,6-dioxaoctane) $\left(=\mathrm{H}_{2} \mathrm{~L}\right)$ Schiff-base has been synthesized and characterized by IR, ${ }^{1} \mathrm{H}$ NMR, mass spectrometry and elemental analysis. Its optimized geometry and theoretical vibrational frequencies have been computed using density functional theory (DFT) method via the B3LYP functional. Also, its ${ }^{1} \mathrm{H}$ and ${ }^{13} \mathrm{C}$ NMR chemical shifts have been calculated at the same computational level. In optimized geometry of the $\mathrm{H}_{2} \mathrm{~L}$, the two pyridine rings are perpendicular to each other. The phenolic hydrogens are engaged in intramolecular-hydrogen bonds with the azomethine nitrogens.
\end{abstract}

KEY WORDS: Schiff base, N,N'-dipyridoxyl(1,8-diamino-3,6-dioxaoctane), DFT, B3LYP

\section{INTRODUCTION}

Schiff bases due to structural varieties and unique characteristics are the most versatile studied ligands in coordination chemistry $[1,2]$ and their metal complexes play an important role in the development of inorganic chemistry [3].

A variety of applications, including biological $[4,5]$, analytical [6, 7] and industrial use as catalysts $[8,9]$, make the Schiff-base ligands and their complexes to be of great importance. It has been shown that the chain length of Schiff bases influences catalytic activity of their complexes [10].

With the continuation of our studies [11-13], here we report the synthesis and experimental characterization of the $\mathrm{N}, \mathrm{N}^{\prime}$-dipyridoxyl(1,8-diamino-3,6-dioxaoctane) $\left(=\mathrm{H}_{2} \mathrm{~L}\right)$ Schiff bases, where the 1,8-diamino-3,6-dioxaoctane moiety acts as a bridge between two dipyridoxyl groups. In addition, geometries optimization and theoretical assignment of the IR, ${ }^{1} \mathrm{H}$ and ${ }^{13} \mathrm{C} \mathrm{NMR}$ spectra of the $\mathrm{H}_{2} \mathrm{~L}$ have been performed by using DFT method, which is widely used as a remarkable method in many areas of the computational chemistry [11-20].

\section{EXPERIMENTAL}

\section{Materials and methods}

All of used chemicals and solvents were purchased from Merck except for pyridoxal hydrochloride which was obtained from Fluka. They were used as received. Melting points were measured by using an Electrothermal 9100 melting point apparatus. Elemental analysis $(\mathrm{C}, \mathrm{H}$, N) was made on a Heraeus elemental analyzer CHN-O-Rapid. The IR spectra were recorded with a PerkinElemer 783 infrared spectrophotometer. Mass spectra were recorded on a Shimadzu-GC-Mass-Qp 1100 Ex. The NMR spectra were recorded in $\left(\mathrm{CD}_{3}\right)_{2} \mathrm{CO}$ on a Bruker Drx-500 Avance spectrometer (500.13 MHz).

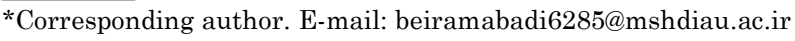


Synthesis of the $\mathrm{H}_{2} \mathrm{~L}$

Pyridoxal hydrochloride $(611 \mathrm{mg}, 3 \mathrm{mmol})$ was dissolved in $5 \mathrm{~mL}$ of methanol, and then was added to methanolic $\mathrm{Et}_{3} \mathrm{~N}$ (303 mg, $3 \mathrm{mmol}$ in $5 \mathrm{~mL}$ ). This mixture was stirred for a few min. Then, a methanolic solution of 1,8-diamino-3,6-dioxaoctane $(669 \mathrm{mg}, 1.5 \mathrm{mmol}$ in $5 \mathrm{~mL}$ ) was slowly added to the mixture, which resulted in synthesis of the $\mathrm{H}_{2} \mathrm{~L}$. The mixture was stirred for $5 \mathrm{~h}$. The orange solid was filtered, washed with cold methanol and dried in air (yield: $30 \%$. decomp. $\left.155^{\circ} \mathrm{C}\right)$.

\section{Computational methods}

All the calculations were performed by using the gradient-corrected DFT method with the B3LYP functional [21] and at $6-31+\mathrm{G}(\mathrm{d}, \mathrm{p})$ basis sets. The Gaussian 03 program package [22] was used with its default procedures. Geometry of the $\mathrm{H}_{2} \mathrm{~L}$ was fully optimized, where the optimized geometry was confirmed to have no imaginary frequency of the Hessian. Then, the gas phase optimized geometry was used to compute theoretical vibrational frequencies of the $\mathrm{H}_{2} \mathrm{~S}$ species. Also, its ${ }^{1} \mathrm{H}$ and ${ }^{13} \mathrm{C}$ NMR chemical shifts were predicted with respect to tetramethylsilane (TMS), where the GIAO method was used for prediction of the DFT nuclear shieldings [23].

\section{RESULTS AND DISCUSSION}

\section{Geometry optimization}

In this work, structural parameters of the $\mathrm{H}_{2} \mathrm{~L}$ species were determined, important of which are gathered in Table 1. For comparison, some structural parameters of the similar compounds are listed in Table 1. The DFT structural parameters of $\mathrm{H}_{2} \mathrm{~L}$ are in agreement with the structural data reported for the similar Schiff-bases [1, 2, 10-13, 24-40], confirming validity of the optimized geometry for the $\mathrm{H}_{2} \mathrm{~L}$ Schiff-base. The optimized geometry of the $\mathrm{H}_{2} \mathrm{~L}$ with atom labelling is shown in Figure 1. In the non-planar geometry of the $\mathrm{H}_{2} \mathrm{~L}$, two pyridine rings are in a separate plane, approximately perpendicular to each other. The pyridine rings are essentially planar; all the substitutions are in the same plane with the corresponding pyridine rings, too.

The calculated bond lengths are in the expected range. As expected, the phenolic $\mathrm{C} 1-\mathrm{O} 1$ and C2-O9 bond lengths (134.0 pm) are shorter than both the alcoholic (142.1 pm) and etheric (142) ones. On the other hand, the alcoholic $\mathrm{O}-\mathrm{H}$ bonds $(96.7 \mathrm{pm})$ are shorter than the phenolic ones $(100.0 \mathrm{pm})$. The phenolic hydrogens are engaged in the intramolecular-hydrogen-bond interactions with the azomethine-nitrogen atoms, which elongates the phenolic $\mathrm{O}-\mathrm{H}$ bonds in comparison with the alcoholic ones. Formation of the intramolecular-hydrogen bond generates six-membered rings. The N...OH and N...O hydrogen bond distances are 169.9 and $259.5 \mathrm{pm}$, respectively, showing strong hydrogen bond interaction. This interaction decreases the electron density in the binding region of the phenolic O-H bonds. The calculated parameters for the $\mathrm{H}_{2} \mathrm{~L}$ are in well agreement with the previously reported values for the similar compounds $[1,2,10$ $13,24-40]$, confirming validity of the optimized geometry for the $\mathrm{H}_{2} \mathrm{~L}$ species.

In this work, the electron populations of the frontier orbitals have been calculated by using the natural bond orbital (NBO) analysis at the B3LYP/6-31+G(d,p) level. The calculated 3-D maps of the highest occupied molecular orbital (HOMO) and lowest unoccupied molecular orbital (LUMO) are shown in Figure 2. As seen, electron clouds of the HOMO orbital are located on the pyridine rings and phenolic oxygens, while the LUMO orbital is located on the $\pi^{*}$ orbital of the $\mathrm{C}=\mathrm{N}$ azomethine groups. 
Table 1. Selected calculated structural parameters of $\mathrm{H}_{2} \mathrm{~L}$ in comparison with the similar compounds.

\begin{tabular}{|c|c|c|}
\hline $\begin{array}{l}\text { Structural } \\
\text { parameters }\end{array}$ & Similar compounds & $\mathrm{H}_{2} \mathrm{~L}$ \\
\hline \multicolumn{3}{|c|}{ Bond lengths (pm) } \\
\hline C1-O1 & $134.1[16] ; 132.0[28] ; 131.6[29] ; 131.1[30] ; 134.1[36] ; 136.1[37]$ & 134.4 \\
\hline $\mathrm{C} 1-\mathrm{C} 2$ & $141.8[16] ; 141.2[30] ; 142.5[33] ; 141.0[37]$ & 141.9 \\
\hline $\mathrm{C} 2-\mathrm{N} 3$ & $132.8[16] ; 132.5[38] ; 133.8[39]$ & 133.0 \\
\hline N3-C3 & $134.8[16] ; 133.6[38] ; 133.8[39] ; 134.0[40]$ & 134.9 \\
\hline C2-C6 & $150.4[16] ; 153.9[37] ; 151.0[40]$ & 150.4 \\
\hline C4-C7 & $152.2[16] ; 152.1[38] ; 151.6[39]$ & 152.3 \\
\hline $\mathrm{C} 7-\mathrm{O} 3$ & $142.0[16] ; 141.9[38] ; 141.2[39]$ & 142.1 \\
\hline C5-C8 & $145.9[16] ; 144.2[30] ; 143.6[32] ; 143.6[33] ; 145.0[36] ; 145.2[37]$ & 146.1 \\
\hline C8-N1 & $128.7[16] ; 129.0[28] ; 129.9[29] ; 128.8[30] ; 128.2[32] ; 128.7[33]$ & 128.7 \\
\hline O1-H1 & $100.0[16] ; 98.9,103.5$ [37] & 100.0 \\
\hline N1-H1 & $169.1[16]$ & 170.0 \\
\hline N1-O1 & $259.5[16]$ & 260.0 \\
\hline O3-H9 & $96.7[16] ; 96.1[39]$ & 96.7 \\
\hline C3-H3 & $108.5[16] ; 107.0[37] ; 108.0,100.0[38]$ & 108.5 \\
\hline C8-H10 & $109.6[16] ; 103.8,107.2$ [29] & 109.7 \\
\hline N1-C17 & $147.7[28] ; 148.2[29] ; 148.0[33] ; 146.1[36] ; 147.6[37]$ & 145.3 \\
\hline $\mathrm{C} 17-\mathrm{C} 18$ & & 152.9 \\
\hline C19-O5 & & 141.8 \\
\hline \multicolumn{3}{|l|}{ Angles $\left({ }^{\circ}\right)$} \\
\hline H1-O1-C1 & 106.9 [16]; $113.1[36] ; 103.4,104.6[37]$ & 107.4 \\
\hline O1-C1-C5 & $122.6[16] ; 123.7[31] ; 123.7[32] ; 121.2[36]$ & 122.5 \\
\hline C1-C5-C8 & $119.9[16] ; 121.2[32] ; 121.6[36] ; 121.1[37] ; 120.8$ [39] & 120.0 \\
\hline $\mathrm{C} 2-\mathrm{N} 3-\mathrm{C} 3$ & $119.4[16] ; 117.5[39] ; 119.9[40]$ & 119.6 \\
\hline C5-C8-N1 & $122.2[16] ; 122.9[29] ; 122.5[30] ; 122.5[36] ; 123.5[37]$ & 122.3 \\
\hline C1-O1-O2 & $76.1[16] ; 163.4$ [29]; 15.9 [31]; 7.3 [33]; 84.9 [36] & 127.5 \\
\hline \multicolumn{3}{|c|}{ Dihedral angles $\left({ }^{\circ}\right)$} \\
\hline H1-O1-C1-C5 & $0.7[16] ; 5.2[37]$ & 0.3 \\
\hline $\mathrm{O} 1-\mathrm{C} 1-\mathrm{C} 5-\mathrm{C} 8$ & $\begin{array}{l}-0.7[16] ;-3.2,0.7[29] ;-1.8,-2.2[30] ;-1.1,-2.0[33] ;-1.5,-1.9[36] ;-2.47 \\
{[37]}\end{array}$ & -0.7 \\
\hline C1-C2-N3-C3 & $0.3[16] ;-0.2[38] ;-0.7,-0.2[39]$ & 0.4 \\
\hline C1-C5-C4-C7 & $179.5[16]$ & -179.7 \\
\hline C1-C5-C8-N1 & $0.5[16] ;-1.7[29] ; 2.6[30] ; 9.8[31] ; 2.0,10.6[33] ; 0.9[36] ; 2.9,-6.6[37]$ & 0.5 \\
\hline O1-N1-N2-O2 & 105.4 [16]; 1.2 [29]; 1.9 [30]; -1.5 [33]; $33.6[36] ;-79.7$ [37] & -103.9 \\
\hline C3-C1-C9-C11 & $-90.5[16] ;-20.4[36] ; 121.5[37]$ & -73.2 \\
\hline C1-O1-O2-C9 & $94.0[16] ; 176.3[31] ; 169.8[33]$ & -79.7 \\
\hline
\end{tabular}

\section{Elemental analysis and mass spectrometry}

The elemental analysis results for the $\mathrm{H}_{2} \mathrm{~L}$ species confirm the proposed formula. Anal. calc. for $\mathrm{C}_{22} \mathrm{H}_{30} \mathrm{~N}_{4} \mathrm{O}_{6}$ : C, $59.2 \%$;, $6.8 \%$; N, $12.6 \%$. Found: C, $59.4 \% ; \mathrm{H}, 6.4 \%$;, $13.1 \%$. Also, the decomposition mass losses of the $\mathrm{H}_{2} \mathrm{~L}$ (MS: $\mathrm{m} / \mathrm{z}(\%) 445\left(\mathrm{M}^{+}\right)$) were found in consistent with the proposed formula.

\section{NMR spectra}

The experimental and theoretical ${ }^{1} \mathrm{H}$ and ${ }^{13} \mathrm{C}$ NMR chemical shifts $(\delta)$ of the $\mathrm{H}_{2} \mathrm{~L}$ Schiff-base are given in Table 2, where the atom positions are numbered as in Figure 1. The appearance of a signal at $13.8 \mathrm{ppm}$ is assigned to the phenolic protons $(\mathrm{H} 1, \mathrm{H} 2)$, where their engagement in the intramolecular hydrogen bond interaction $(\mathrm{O}-\mathrm{H} \ldots \mathrm{N})$, shifts their signals to upfield [23, 41]. 

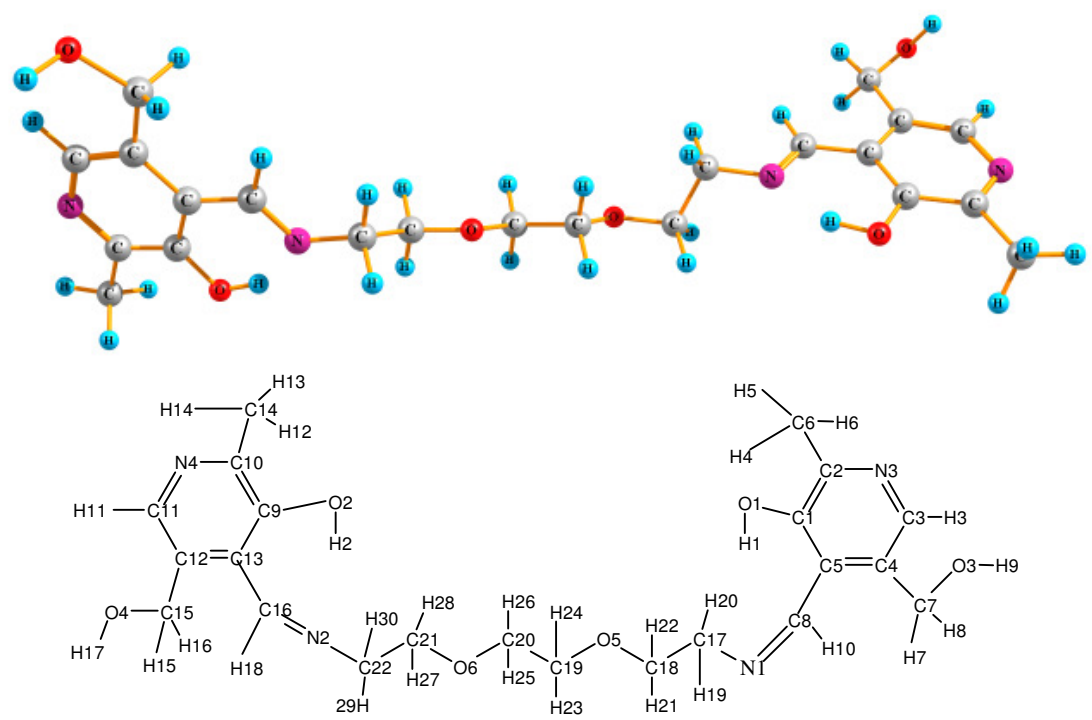

Figure 1. Structure and B3LYP optimized geometry of the N,N'-dipyridoxyl(1,8-diamino-3,6dioxaoctane) together with its atom labelling.
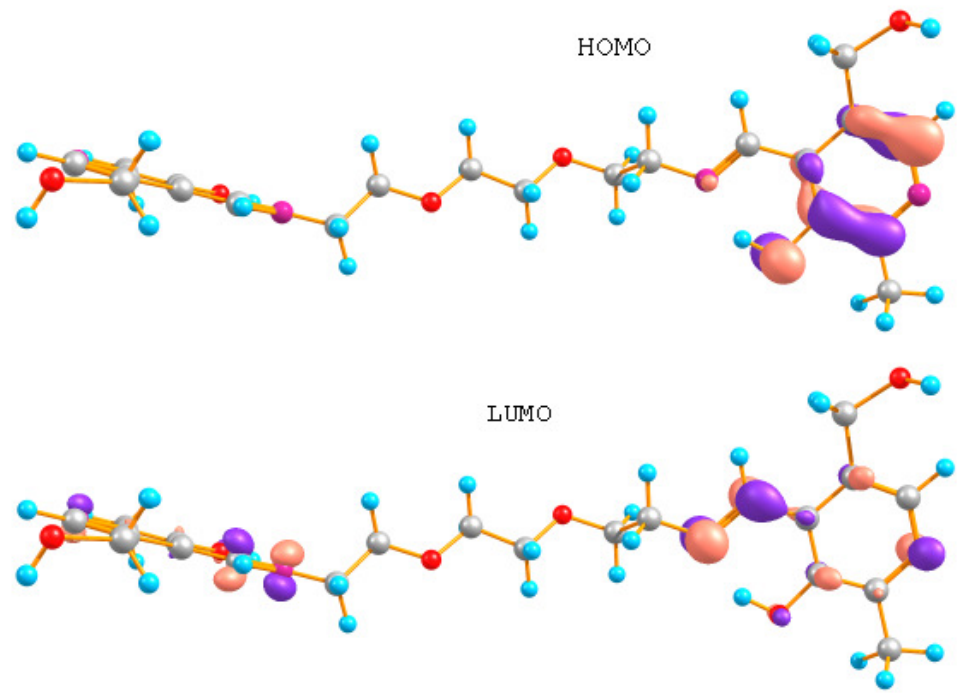

Figure 2. The HOMO and LUMO frontier orbitals of the N,N'-dipyridoxyl(1,8-diamino-3,6dioxaoctane). 
Table 2. Experimental and theoretical ${ }^{1} \mathrm{H}$ - and ${ }^{13} \mathrm{C}$-NMR chemical shifts of $\mathrm{N}, \mathrm{N}^{\prime}$-dipyridoxyl(1,8-diamino3,6-dioxaoctane) in $\left(\mathrm{CD}_{3}\right)_{2} \mathrm{CO}$ solution, $\delta$ [ppm].

\begin{tabular}{|l|l|l|l|l|l|l|l|l|l|l|l|}
\hline \multicolumn{9}{|c|}{${ }^{1}$ H NMR } & \multicolumn{5}{c|}{${ }^{13}$ C NMR } \\
\hline $\begin{array}{l}\text { Atom } \\
\text { position }\end{array}$ & Exp. & Theo. & $\begin{array}{l}\text { Atom } \\
\text { position }\end{array}$ & Exp. & Theo. & $\begin{array}{l}\text { Atom } \\
\text { position }\end{array}$ & Exp. & Theo. & $\begin{array}{l}\text { Atom } \\
\text { position }\end{array}$ & Exp. & Theo. \\
\hline H1 & 13.8 & 14.1 & H28 & 3.8 & 4.7 & C8 & 163.7 & 148.2 & C20 & 69.6 & 59.2 \\
\hline H2 & 13.8 & 14.1 & H21 & 3.6 & 4.6 & C16 & 163.7 & 148.0 & C17 & 69.5 & 53.4 \\
\hline H10 & 8.9 & 9.4 & H22 & 3.6 & 4.6 & C1 & 156.1 & 140.7 & C22 & 69.5 & 53.4 \\
\hline H18 & 8.9 & 9.4 & H25 & 3.6 & 4.6 & C9 & 156.1 & 140.6 & C7 & 58.5 & 51.8 \\
\hline H3 & 7.8 & 9.2 & H26 & 3.6 & 4.4 & C2 & 149.5 & 137.5 & C15 & 58.5 & 51.8 \\
\hline H11 & 7.8 & 9.2 & H30 & 3.8 & 4.1 & C10 & 149.5 & 137.5 & C8 & 57.6 & 51.3 \\
\hline H8 & 4.7 & 6.0 & H19 & 3.8 & 3.8 & C3 & 135.5 & 120.4 & C16 & 57.6 & 51.3 \\
\hline H15 & 4.7 & 6.0 & H4 & 2.4 & 3.4 & C11 & 135.5 & 120.2 & C6 & 16.7 & 12.3 \\
\hline H16 & 4.7 & 5.8 & H5 & 2.4 & 3.4 & C4 & 132.6 & 119.4 & C14 & 16.7 & 12.3 \\
\hline H7 & 4.7 & 5.8 & H12 & 2.4 & 3.4 & C12 & 132.6 & 119.3 & & & \\
\hline H20 & 3.8 & 5.3 & H13 & 2.4 & 3.4 & C5 & 119.3 & 103.8 & & & \\
\hline H29 & 3.8 & 5.1 & H6 & 2.4 & 3.0 & C13 & 119.3 & 103.6 & & & \\
\hline H24 & 3.8 & 4.9 & H14 & 2.4 & 3.0 & C18 & 69.6 & 62.1 & & & \\
\hline H27 & 3.8 & 4.7 & H9 & 4.8 & 0.7 & C21 & 69.6 & 62.0 & & & \\
\hline H23 & 3.8 & 4.7 & H17 & 4.8 & 0.7 & C19 & 69.6 & 60.5 & & & \\
\hline
\end{tabular}

The calculated chemical shifts are in good agreement with the experimental values, confirming suitability of the optimized geometry for the $\mathrm{H}_{2} \mathrm{~L}$ species. The only exception is the chemical shift of the alcoholic protons (H9 and H17), where their experimental chemical shifts are significantly higher than the calculated ones. The experimental data are from $\left(\mathrm{CD}_{3}\right)_{2} \mathrm{CO}$ solutions but the calculations correspond to the isolated molecule in the gas phase. Obviously, the solvent molecules interact with the alcoholic proton. Also, the alcoholic protons may engage in intermolecular hydrogen bonds.

\section{Vibrational spectroscopy}

Theoretical investigation of the IR and NMR spectra could be used as an important tool for identification of chemical species, especially evaluation of proposed geometries for compounds with undeterminated X-ray structure [10-14, 42]. The selected DFT vibrational frequencies of the $\mathrm{H}_{2} \mathrm{~L}$ are listed in Table 3. The vibrational modes were analyzed by comparing the previously reported data [28, 30-32] with the present work.

In the $3600-2000 \mathrm{~cm}^{-1}$ spectral region of the IR spectra, overlapping of stretching vibrations of the $\mathrm{O}-\mathrm{H}$ bonds with each other and with the $\mathrm{C}-\mathrm{H}$ stretching modes causes to a band broadening [10-13, 32, 33]. In Table 3, deconvolution of this region is given, where the most intensive band is related to the stretching vibrations of the phenolic $\mathrm{O}-\mathrm{H}$ bonds. These vibrations are appeared at lower energies than the alcoholic $\mathrm{O}-\mathrm{H}$ ones. The very intensive bands at $1660-1500 \mathrm{~cm}^{-1}$ region accounts as an important band in the infrared spectra of the Schiffbases [10-13, 43-45]. Here, a very intensive band at $1641 \mathrm{~cm}^{-1}$ region of the IR spectrum is attributed to the symmetrical stretching modes of $\mathrm{C} 8=\mathrm{N} 1$ and $\mathrm{C} 16=\mathrm{N} 2$ bonds. Vibrational modes of the bridge region causes to appearance of some absorption bands, important of which are assigned in Table 3. 
Table 3. Selected experimental and calculated IR vibrational frequencies $\left(\mathrm{cm}^{-1}\right)$ of the $\mathrm{H}_{2} \mathrm{~L}$.

\begin{tabular}{|c|c|c|c|}
\hline \multirow{2}{*}{$\begin{array}{l}\text { Experimental } \\
\text { frequencies }\end{array}$} & \multicolumn{2}{|c|}{ Calculated } & \multirow{2}{*}{ Vibrational assignment } \\
\hline & Frequencies & Intensity & \\
\hline $731(w)$ & 731 & 20 & Breathing of pyridine ring \\
\hline $892(\mathrm{~m})$ & 891 & 83 & $\delta_{\text {oot-of-plane }}(\mathrm{O}-\mathrm{H})$ phenolic \\
\hline $998(\mathrm{~s})$ & 1027 & 23 & $v_{\text {sym }}(\mathrm{C}-\mathrm{O}-\mathrm{C})$ ether \\
\hline $1041(\mathrm{~s})$ & 1075 & 50 & $\delta(\mathrm{CH}) \mathrm{Me}^{\mathrm{a}}+\mathrm{v}(\mathrm{C}-\mathrm{O}) \mathrm{alc}^{\mathrm{b}}+\mathrm{v}(\mathrm{C} 17-\mathrm{N} 1, \mathrm{C} 16-\mathrm{N} 2)$ \\
\hline $1136(\mathrm{~s})$ & 1162 & 472 & $V_{\text {asym }}(\mathrm{C}-\mathrm{O}-\mathrm{C})$ ether \\
\hline $1197(\mathrm{~m})$ & 1246 & 49 & $\begin{array}{l}v(\mathrm{ph}-\mathrm{C})+v(\mathrm{C} 1-\mathrm{C} 2, \mathrm{~N} 3-\mathrm{C} 3, \mathrm{C} 4-\mathrm{C} 5, \mathrm{C} 9-\mathrm{C} 10, \mathrm{~N} 4-\mathrm{C} 11, \mathrm{C} 12- \\
\mathrm{C} 13)\end{array}$ \\
\hline $1271(\mathrm{~s})$ & 1314 & 53 & $\delta_{\text {wagging }}\left(\mathrm{CH}_{2}\right)$ bridge $^{\mathrm{c}}$ \\
\hline $1314(\mathrm{~s})$ & 1399 & 63 & {$\left[\delta_{\text {twisting }}\left(\mathrm{CH}_{2}\right)+\delta_{\text {in-planep }}(\mathrm{OH})\right] \mathrm{alc}^{\mathrm{b}}$} \\
\hline 1406 (vs) & 1439 & 108 & $\begin{array}{l}v(\mathrm{C} 1-\mathrm{O} 1)+v(\mathrm{C} 9-\mathrm{O} 2)+v(\text { ph ring })+v(\text { ph-C })+v(\mathrm{C} 9-\mathrm{O} 2)+ \\
v(\text { ph ring }))+v(\text { ph-C }) \text { right }^{\mathrm{e}}\end{array}$ \\
\hline 1641 (vs) & 1692 & 189 & $v(\mathrm{C} 8-\mathrm{N} 1), v(\mathrm{C} 16-\mathrm{N} 2)$ \\
\hline \multirow{2}{*}{$2896(\mathrm{~s})$} & 2984,2999 & 28,59 & $\mathrm{~V}_{\mathrm{sym}}(\mathrm{CH})$ bridge \\
\hline & 3004 & 74 & $\mathrm{v}_{\mathrm{sym}}(\mathrm{CH}) \mathrm{alc}^{\mathrm{b}}$ \\
\hline \multirow{2}{*}{$2928(\mathrm{sh})$} & 3024 & 47 & $V_{\text {asym }}(\mathrm{CH})$ bridge $^{\mathrm{c}}$ \\
\hline & 3043 & 20 & $\nu_{\text {sym }}(\mathrm{CH}) \mathrm{Me}^{\mathrm{a}}$ \\
\hline \multirow{3}{*}{$2948(\mathrm{sh})$} & 3053 & 74 & $\mathrm{~V}_{\text {asym }}(\mathrm{CH})$ bridge $^{\mathrm{c}}$ \\
\hline & 3063 & 91 & $v\left(\mathrm{C}_{8} \mathrm{H}_{10}\right)+v\left(\mathrm{C}_{16}-\mathrm{H}_{18}\right)$ \\
\hline & 3071 & 13 & $\mathrm{~V}_{\text {asym }}(\mathrm{CH}) \mathrm{alc}^{\mathrm{b}}$ \\
\hline \multirow{6}{*}{3148 (br, s) } & 3075 & 22 & $\mathrm{~V}_{\text {asym }}(\mathrm{CH})$ bridge $^{\mathrm{c}}$ \\
\hline & 3096 & 13 & $V_{\text {asym }}(\mathrm{CH}) \mathrm{Me}^{\mathrm{a}}$ \\
\hline & 3102 & 35 & $V_{\text {asym }}(\mathrm{CH})$ bridge $^{\mathrm{c}}$ \\
\hline & 3122,3124 & 708,296 & $\mathrm{v}(\mathrm{O}-\mathrm{H})$ phenolic \\
\hline & 3208 & 7 & $v(\mathrm{C}-\mathrm{H})$ aromatic \\
\hline & 3814 & 32 & $v(\mathrm{O}-\mathrm{H}) \mathrm{alc}^{\mathrm{b}}$ \\
\hline
\end{tabular}

Abbreviation: a: substituted $-\mathrm{CH}_{3}$ groups; b: substituted $-\mathrm{CH}_{2} \mathrm{OH}$ groups; c: N1-bridge region of molecule- $\mathrm{N} 2 ; \mathrm{d}$ : left side of the molecule; e: right side of the molecule; w, weak; m, medium; s, strong; vs, very strong; sh, shoulder; br, broad.

\section{CONCLUSION}

In this work, we have synthesized and characterized a new Schiff-base $\left(\mathrm{H}_{2} \mathrm{~L}\right)$. The geometry optimization, ${ }^{1} \mathrm{H}$ and ${ }^{13} \mathrm{C}$ NMR chemical shifts and IR vibrational frequencies of the $\mathrm{H}_{2} \mathrm{~L}$ have been calculated using DFT methods. The calculated results are in agreement with the experimental evidence, confirming validity of the optimized geometry for the $\mathrm{H}_{2} \mathrm{~L}$.

The $\mathrm{H}_{2} \mathrm{~L}$ molecule is not planar, but two pyridine rings are roughly perpendicular to each other. However, the substituents are in a same plane with the pyridine rings. The intramolecular hydrogen bonds between the phenolic protons and the azomethine nitrogens changes chemical shifts of the phenolic protons to $13.8 \mathrm{ppm}$ in the ${ }^{1} \mathrm{H}$ NMR spectrum of the free $\mathrm{H}_{2} \mathrm{~L}$ ligand. In addition, important IR vibrational frequencies of the $\mathrm{H}_{2} \mathrm{~L}$ have been assigned using DFT calculations. The obtained results could be used for identification of similar compounds.

\section{REFERENCES}

1. Yu, D.; Xiaoxia, H.; Xiaoli, S.; Zhiling, Z. Wuhan Univ. J. Nat. Sci. 2010, 15, 165.

2. Kumar, D.; Gupta, P.K.; Syamal, A. J. Chem. Sci. 2005, 117, 247. 
3. Valent, A.; Melník, M.; Hudecová, D.; Dudová, B.; Kivekäs, R.; Sundberg, M.R. Inorg. Chim. Acta 2002, 340, 15.

4. Lamour, E.; Routier, S.; Bernier, J.L.; Catteau, J.P.; Bailly, C.; Vezin, H. J. Am. Chem. Soc. 1999, 121, 1862.

5. Morrow, J.R.; Kolasa K. Inorg. Chim. Acta 1992, 195, 245.

6. Sadeghi, S.; Gafarzadeh, A.; Naeimi, H. J. Anal. Chem. 2006, 61, 677.

7. Dadfarnia, S.; Haji Shabani, A.M.; Tamadon, F.; Rezaei, M. Microchim. Acta 2007, 158, 159.

8. Sakthivel, A.; Sun, W.; Raudaschl-Sieber, G.; Chiang, A.S.T.; Hanzlik, M.; Kühn, F.E. Catal. Commun. 2006, 7, 302.

9. Gupta, K.C., Sutar, A.K. J. Mol. Catal. A: Chem. 2007, 272, 64.

10. Gupta, K.C.; Sutar, A.K. Coord. Chem. Rev. 2008, 252, 1420.

11. Eshtiagh-Hosseini, H.; Housaindokht, M.R.; Beyramabadi, S.A.; Beheshti, S.; Esmaeili, A.A.; Javan-Khoshkholgh, M.; Morsali, A. Spectrochim. Acta Part A 2008, 71, 1341.

12. Eshtiagh-Hosseini, H.; Housaindokht, M.R.; Beyramabadi, S.A.; Mir Tabatabaei, S.H.; Esmaeili, A.A.; Javan-Khoshkholgh, M. Spectrochim. Acta Part A 2011, 78, 1046.

13. Beyramabadi, S.A.; Morsali, A.; Javan-Khoshkholgh, M.; Esmaeili, A.A., J. Struct. Chem. 2011, 53, 460 .

14. Eshtiagh-Hosseini, H.; Aghabozorg, H.; Mirzaei, M.; Beyramabadi, S.A.; Eshghi, H.; Morsali, A.; Shokrollahi, A.; Aghaei, R. Spectrochim. Acta Part A 2011, 78, 1392.

15. Beyramabadi, S.A.; Eshtiagh-Hosseini, H.; Housaindokht, M.R.; Morsali, A. Organometallics 2008, 27, 72 .

16. Beyramabadi, S.A.; Eshtiagh-Hosseini, H.; Housaindokht, M.R.; Morsali A. J. Mol. Struct.: THEOCHEM 2009, 903, 108.

17. Alkorta, I.; Elguero, J.; Roussel C. Comput. Theor. Chem. 2011, 966, 334.

18. Alver, Ö.; Parlak, C.; Bilge, M. Bull. Chem. Soc. Ethiop. 2011, 25, 437.

19. Alver, Ö.; Parlak, C.; Şenyel, M. Bull. Chem. Soc. Ethiop. 2009, 23, 85.

20. Vessally, E. Bull. Chem. Soc. Ethiop. 2008, 22, 465.

21. Lee, C.; Yang, W.; Parr, R.G. Phys. Rev. B 1988, 37, 785.

22. Frisch, M.J.; Trucks, G.W.; Schlegel, H.B.; Scuseria, G.E.; Robb, M.A.; Cheeseman, J.R.; Montgomery, J.A.; Vreven, T.; Kudin, K.N.; Burant, J.C.; Millam, J.M.; Iyengar, S.S.; Tomasi, J.; Barone, V.; Mennucci, B.; Cossi, M.; Scalmani, G.; Rega, N.; Petersson, G.A.; Nakatsuji, H.; Hada, M.; Ehara, M.; Toyota, K.; Fukuda, R.; Hasegawa, J.; Ishida, M.; Nakajima, T.; Honda, Y.; Kitao, O.; Nakai, H.; Klene, M.; Li, X.; Knox, J.E.; Hratchian, H.P.; Cross, J.B.; Bakken, V.; Adamo, C.; Jaramillo, J.; Gomperts, R.; Stratmann, R.E.; Yazyev, O.; Austin, A.J.; Cammi, R.; Pomelli, C.; Ochterski, J.W.; Ayala, P.Y.; Morokuma, K.; Voth, G.A.; Salvador, P.; Dannenberg, J.J.; Zakrzewski, V.G.; Dapprich, S.; Daniels, A.D.; Strain, M.C.; Farkas, O.; Malick, D.K.; Rabuck, A.D.; Raghavachari, K.; Foresman, J.B.; Ortiz, J.V.; Cui, Q.; Baboul, A.G.; Clifford, S.; Cioslowski, J.; Stefanov, B.B.; Liu, G.; Liashenko, A.; Piskorz, P.; Komaromi, I.; Martin, R.L.; Fox, D.J.; Keith, T.; Al-Laham, M.A.; Peng, C.Y.; Nanayakkara, A.; Challacombe, M.; Gill, P.M.W.; Johnson, B.; Chen, W.; Wong, M.W.; Gonzalez, C.; Pople, J.A., Gaussian 98, Revision A.7, Gaussian, Inc.: Pittsburgh PA; 1998.

23. Ditchfield, R. Mol. Phys. 1974, 27, 789.

24. Kumari, D.; Syamal, A.; Jaipal, Kumar Sharma, L. J. Chem. Sci. 2009, 121, 57.

25. Deters, R.; Krämer, R. Inorg. Chim. Acta 1998, 269, 117.

26. Al-Jeboori, M.J.; Hasan, H.A.; Al-Sa'idy, W.A.J. Transition, Met. Chem. 2009 34, 593.

27. Soto-Garrido, G.; Salas-Reyes, V. Transition Met. Chem. 2000, 25, 192.

28. Khandar, A.A.; Shaabani, B.; Belaj, F.; Bakhtiari, A. Polyhedron 2006, 25, 1893. 
29. Chen, H.; Han, D.; Yan, H.; Tang, W.; Yang, Y.; Yang, W. Acta Cryst. 1996, C52, 2204. 30. Sato, S.; Fukuda, T.; Ishii, K.; Nakano, Y.; Fujii, Y. Acta Cryst. 1999, C55, 1466.

31. Meghdadi, S.; Mahmoudkhani, A.H. Acta Cryst. 2006, E62, m69.

32. You, Z.-L.; Qu, Y.; Liu, W.-S.; Tan, M.-Y.; Zhu, H.-L. Acta Cryst. 2003, E59, m1038.

33. Sun, Y.-X. Acta Cryst. 2005, E61, m39.

34. Li, S.-Y.; You, Z.-L.; Chen, B.; Lin, Y.-S.; Xiong, Z.-D.; Zhu, H.-L. Acta Cryst. 2004, E60, m999.

35. You, Z.-L.; Zhu, H.-L.; Liu, W.-S. Acta Cryst. 2004, E60, m587.

36. Yang, M.-H.; Li, Y.-Z.; Zhu, C.-J.; Pan, Y.; Liu S.-H. Acta Cryst. 2004, E60, o2397.

37. Yoon, J.W.; Yoon, T.-S.; Shin, W. Acta Cryst. 1997, C53, 1685.

38. Mantero, D.G.; Altaf, M.; Neels, A.; Stoeckli-Evans, H. Acta Cryst. 2006, E62, o5204.

39. Kuroda, R.; Saito, Y. Acta Cryst. 1974, B30, 2126.

40. Sağlam, A.; Ucun, F.; Güçlü, V. Spectrochim. Acta Part A 2007, 67, 465.

41. Pui, A.; Policar, C.; Mahy, J.P. Inorg. Chim. Acta 2007, 360, 2139.

42. Avcı, D.; Atalay, Y.; Şekerci, M.; Dinçer, M. Spectrochim. Acta Part A 2009, 73, 212.

43. Parimala, S.; Gita, K.N.; Kandaswamy, M. Polyhedron 1998, 17, 3445.

44. Sanmartín, J.; García-Deibe, A.M.; Fondo, M.; Navarro, D.; Bermejo, M.R. Polyhedron 2004, 23, 963.

45. Ware, D.C.; Mackie, D.S.; Brothers, P.J.; Denny, W.A. Polyhedron 1995, 14, 1641. 